(2. THE EAST-WEST CENTER-officially known as the Center for Cultural and Technical Interchange Between East and West-is a national educational institution established in Hawaii by the U.S. Congress in 1960 to promote better relations and understanding between the United States and the nations of Asia and the Pacific through cooperative study, training, and research. The Center is administered by a public, nonprofit corporation whose international Board of Governors consists of distinguished scholars, business leaders, and public servants.

Each year more than 1,500 men and women from many nations and cultures participate in Center programs that seek cooperative solutions to problems of mutual consequence to East and West. Working with the Center's multidisciplinary and multicultural staff, participants include visiting scholars and researchers; leaders and professionals from the academic, government, and business communities; and graduate degree students, most of whom are enrolled at the University of Hawaii. For each Center participant from the United States, two participants are sought from the Asian and Pacific area.

Center programs are conducted by institutes addressing problems of communication, culture learning, environment and policy, population, and resource systems. A limited number of "open" grants are available to degree scholars and research fellows whose academic interests are not encompassed by institute programs.

The U.S. Congress provides basic funding for Center programs and a variety of awards to participants. Because of the cooperative nature of Center programs, financial support and cost-sharing are also provided by Asian and $\mathrm{Pa}$ cific governments, regional agencies, private enterprise and foundations. The Center is on land adjacent to and provided by the University of Hawaii.

East-West Center Books are published by The University Press of Hawaii to further the Center's aims and programs. 


\section{PROPAGANDA AND COMMUNICATION}

IN WORLD HISTORY

VOLUME I The Symbolic Instrument in Early Times

VOLUME II Emergence of Public Opinion in the West

VoLUME III A Pluralizing World in Formation 


\section{PROPAGANDA AND COMMUNICATION IN WORLD HISTORY}

\section{VOLUME II}

Emergence of Public Opinion in the West

edited by

Harold D. Lasswell

Daniel Lerner

Hans Speier

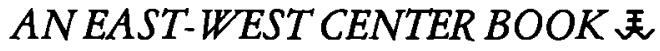

Published for the East-West Center by

The University Press of Hawaii

Honolulu 
Copyright (ㄷ 1980 by the East-West Center

All rights reserved

Manufactured in the United States of America

"The Enlightenment as a Communication Universe" is adapted and expanded by Peter Gay from The Enlightenment: An Interpretation, Vol. 1, by Peter Gay. Copyright (c) 1966 by Peter Gay. Reprinted by permission of Alfred A. Knopf, Inc.

"Millenarianism as a Revolutionary Force" by Guenter Lewy is reprinted by permission of Oxford University Press from Guenter Lewy's Religion and Revolution. Copyright (C) 1974 by Oxford University Press.

"Thoughts on Progress, Peaceful Coexistence and Intellectual Freedom" by Andrei D. Sakharov, and "Appendix: People Mentioned," appeared in The New York Times, 22 July 1968. Copyright (C) 1968 by The New York Times Company. Reprinted by permission.

\section{Library of Congress Cataloging in Publication Data}

Main entry under title:

Emergence of public opinion in the West.

(Propaganda and communication in world history ; v. 2)

"An East-West Center book."

Includes index.

1. Public opinion-History. 2. Propaganda-History.

3. Communication in politics-History. 4. Social movements--History. I. Lasswell, Harold Dwight, 1902- II. Lerner, Daniel. III. Speier, Hans, 1905- IV. Series.

HM258.P74 vol. 2 [HM261] 301.14s [301.15'4'09]

ISBN 0-8248-0504-6 
These three volumes are dedicated to

JEAN LERNER

our indispensable collaborator

who, with insight, skill, and good cheer,

did whatever needed to be done

through the years of these studies 
